\title{
Effect of probiotic Pediococcus acidilactici on antioxidant defences and oxidative stress of Litopenaeus stylirostris under Vibrio nigripulchritudo challenge
}

\author{
Mathieu Castex ${ }^{\mathrm{a},{ }^{*}}$, Pierrette Lemaire $^{\mathrm{a}}$, Nelly Wabete $^{\mathrm{a}}$ and Liet Chim ${ }^{\mathrm{a}}$ \\ a IFREMER, Département Aquaculture en Nouvelle-Calédonie, BP 2059, 98.46 Nouméa Cedex, New Caledonia, \\ France \\ *: Corresponding author: Mathieu Castex, Tel.: +33 6873525 84; fax: +33 6873511 77, email address : \\ mcastex@lallemand.com
}

\begin{abstract}
:
Antioxidant defences and induced oxidative stress tissue damage of the blue shrimp Litopenaeus stylirostris, under challenge with Vibrio nigripulchritudo, were investigated for a 72-h period. For this purpose, $L$. stylirostris were first infected by immersion with pathogenic $V$. nigripulchritudo strain SFn1 and then antioxidant defences: superoxide dismutase (SOD), catalase (CAT), glutathione peroxidase (Gpx), Total antioxidant status (TAS), glutathiones and induced tissue damage (MDA and carbonyl proteins) were determined in the digestive gland at $0,12,24,48$ and $72 \mathrm{~h}$ post-infection (h.p.i.). In the meantime, TAS was also measured in the blood. Infection level of the shrimps during the challenge was followed by determining $V$. nigripulchritudo prevalence and load in the haemolymph of the shrimps. Changes in all these parameters during the 72-h.p.i. period were recorded for control shrimps and shrimps previously fed for one month with probiotic Pediococcus acidilactici MA18/5M at $10^{7} \mathrm{CFU} \mathrm{g}{ }^{-1}$ of feed.
\end{abstract}

Our results showed that immersion with $V$. nigripulchritudo led to maximal infection level in the haemolymph at 24 h.p.i. preceding the mortality peak recorded at 48 h.p.i. Significant decreases in the antioxidant defences were detected from 24 h.p.i. and beyond that time infection leaded to increases in oxidative stress level and tissue damage. Compared to control group, shrimps fed the probiotic diet showed lower infection (20\% instead of $45 \%$ at 24 h.p.i. in the control group) and mortality (25\% instead of $41.7 \%$ in the control group) levels. Moreover, infected shrimp fed the probiotic compared to uninfected control shrimps exhibited very similar antioxidant status and oxidative stress level. Compared to the infected control group, shrimps fed the probiotic sustained higher antioxidant defences and lower oxidative stress level.

This study shows that bacterial infection leads to oxidative stress in L. stylirostris and highlighted a beneficial effect of $P$. acidilactici, suggesting both a competitive exclusion effect leading to a reduction of the infection level and/or an enhancement of the antioxidant status of the shrimps.

Keywords: Probiotic; Pediococcus acidilactici; Shrimp; Oxidative stress; Antioxidant status; Vibrio; Immersion challenge 


\section{Introduction}

In recent years, infectious and non-infectious disease and environmental pollution have seriously affected cultured shrimps [1]. Viral infection remains the main problem and is responsible for major economic loss in the aquaculture industry worldwide. Vibriosis has been also implicated as the cause of high mortality in juvenile penaeid shrimp [2]. For example, shrimp farming in New Caledonia today faces two diseases involving bacterial pathogens: "Syndrome 93" [3] and "Summer syndrome" [4]. Therefore the development of solutions for improved resistance and survival of shrimps in fluctuating environments and with pathogen infection is crucial to sustain the growth of the shrimp culture industry. Among the solutions proposed, the use of probiotic has shown promising results and is now widely accepted as a complementary tool for the alternative management of disease and for improving nutrition of aquatic animals [5].

All living organisms are under constant attack from free radicals, which can lead to serious cellular damage if produced in excess. Reactive oxygen species (ROS) are naturally produced in animals during normal aerobic metabolism [6]. Many stress conditions like temperatures at the edge of thermal windows of the specie or hypoxia lead to an increased production of ROS resulting in "oxidative stress" (OS) inside the cell (reviewed by Kassahn et al., 2009 [7]). For instance, superoxide is considered as the major free radical stressproduced by living cells [8]. However, ROS production also comes as part of the immune defence system and plays an important role in microbicidal activity [9]. In decapods crustaceans, haemocytes are involved in the immune response to pathogen infection via phagocytosis and melanin production through the prophenoloxidase system [10]. Phagocytosis is a common cellular defence response generally recognized as a central and important way to eliminate micro-organisms and foreign particles. Once a pathogen enters the haemolymph, NADPH-oxidase is then activated in the haemocyte of the host, which in turn reduces oxygen to the superoxide anion, subsequently leading to the production of ROS as hydrogen peroxide, singlet oxygen, hydroxyl radicals and numerous other reactive compounds [9]. This process, called respiratory burst, has been reported in several shrimp species, including Litopenaeus stylirostris [11]. However, although ROS play an important role in host defence, their over-expression and residual ROS can result in OS.

The antioxidant defence system of the organism, including enzymes such superoxide dismutase (SOD), catalase (CAT) and glutathione peroxidise (Gpx), is set to maintain the lowest possible levels of ROS in the cell, and is recognised as an essential component of an organism's self-maintenance. Moreover, the antioxidant defence system and the immune system are closely linked in the response to pathogens [12]. Therefore the implication of the antioxidant defence system in the development of disease through its ability to limit OS induced by respiratory burst activity and/or deleterious effects of poor environmental conditions, even if poorly investigated in shrimp, may be crucial.

However, most of the studies on OS in shrimps are restricted to its presence and role during exposure to xenobiotics or environmental perturbations $[6,13]$. Experimental investigations on alteration of animal antioxidant defence system in pathogenic infectious disease remain scarce. Recent studies have shown changes in some antioxidant enzymes activity such as superoxide dismutase, catalase and glutathione peroxydase, and oxidative damages (lipid peroxydation) in various tissues in $P$. monodon infected with WSSV [14, 15]. In addition, several studies have also shown changes in SOD activity $[16,17,18]$ and in SOD, Gpx and CAT expression following bacterial infection or virus challenges [19, 20, 21]. It has also been suggested that the antioxidant defences operate at a very much lower rate in infected shrimps despite the higher requirement for dismutation of harmful free radical formation during infection by pathogens [15].

Based on this claim, it has been proposed that dietary supplementation of products with antimicrobial and antioxidant properties may be a promising disease prevention option for increasing resistance of shrimps to pathogens [15]. For instance, Chiu et al. (2007) [22] reported that administering Lactobacillus plantarum can enhance the antioxidant status of 
Litopenaeus vannamei and could lead to increased resistance to $V$. alginolyticus infection. However, except for SOD activity [23], up to day no study has been found reporting significant effect of such dietary products, including probiotics, on the antioxidant response in shrimps following pathogen challenges.

In a previous study we showed that one month feeding with a diet enriched with $1 \mathrm{~g} . \mathrm{kg}^{-1}$ of Pediococcus acidilactici MA18/5M resulted in an increased survival rate, changes in antioxidant enzymes activity and higher total antioxidant status (TAS) of Litopenaeus stylirostris [24]. Moreover, this previous study also highlighted that after natural infection by V. nigripulchritudo, probiotic-fed shrimps showed an increased survival rate and lower OS damages in their digestive gland. Therefore the present study was carried out in order to investigate, under controlled conditions, how probiotic $P$. acidilactici treatment influences antioxidant defences and OS development in shrimps experimentally challenged with $V$. nigripulchritudo.

\section{Materials and Methods}

\subsection{Experimental shrimps, impregnation period and feeding}

The shrimps L. stylirostris used in our experiments were reared semi-intensively (without aeration) in earthen ponds $\left(1000 \mathrm{~m}^{2}\right)$ at the Saint-Vincent station (Ifremer). Six hundred L. stylirostris juveniles $(12.79 \pm 2.72)$ were fished in earthen ponds, transferred to the laboratory and acclimated into 6 circular polyester tanks (capacity $1600 \mathrm{~L}$ ) for one week prior to the beginning of the experiment. Each tank was continuously oxygenated by injection of high pressure air and supplied with seawater pumped into the lagoon with a water renewal rate of $200 \%$ per day. Temperature was measured continuously (every hour) using an automatic recording probe (Optic StowAway® Temp; Onset).

Tanks were then assigned to two different dietary treatments: four tanks were fed with a control diet, while the remaining two tanks received the probiotic diet. Shrimps were fed for one month with the two diets, distributed four times a day and provided ad libitum. The amount of feed was adjusted daily to minimise left-over feed. The water temperature was $26.0 \pm 1.9^{\circ} \mathrm{C}$ and salinity was $35 \%$ throughout.

\subsection{Feeds and probiotic}

Shrimps were fed an experimental feed processed in the laboratory as previously described [24]. The commercial probiotic preparation tested was Bactocell ${ }^{\circledR}$ PA 10 (Lallemand Animal Nutrition S.A., Blagnac, France) formulated with live Pediococcus acidilactici MA 18/5 M (Institut Pasteur, Paris, France). For the treated group, $1 \mathrm{~g} \cdot \mathrm{kg}^{-1}$ of the probiotic (powder form) was top-coated on the pellets using $2 \%$ of fish oil as a carrier, giving a final concentration of $0.9 \times 10^{7}$ CFU of $P$. acidilactici per gram of diet. The control diet was also top-coated with $2 \%$ fish oil and, prior to use, checked for possible contamination by the probiotic strain. The feed was then stored in 5 -litre boxes at $20^{\circ} \mathrm{C}$ until use.

\subsection{Challenge with $V$. nigripulchritudo by immersion}

After one month of rearing, intermoult shrimps were transferred in the experimental room for immersion challenge with $V$. nigripulchritudo. The experimental challenge was made in a controlled area allowing the disinfection of the waste water before its release into the lagoon. Shrimps were assigned to twenty-four $300 \mathrm{~L}$ fibre glass tanks filled with $5 \mu \mathrm{m}$-filtered seawater, aerated and held at $27^{\circ} \mathrm{C}$. Shrimp were acclimatized for one week prior to the challenge test using a previously described protocol to reduce transfer stress and to lower physiological disturbances [25]. Shrimp were continuously fed at $2 \%$ of the tank biomass four 
times daily with one of the two diets according the treatment, and water was renewed continuously.

Shrimps were infected by immersion for two hours with $V$. nigripulchritudo. A short contact period is preferred in order to prevent possible bacterial reinfection during the experimental survey [26]. The V. nigripulchritudo pathogenic strain SFn1 [4] was cultured beforehand in Marine Broth for $18 \mathrm{~h}$ at $30^{\circ} \mathrm{C}$ under constant shaking, allowing the late exponential growth phase to be reached. The bacterial culture concentrations were evaluated by reading their optical density at $600 \mathrm{~nm}$, as compared to a previously determined reference curve (data not shown). Three treatments were then carried out: control shrimps, infected control shrimps and infected probiotic shrimps. Shrimps were infected by inoculating tanks with $10^{5} \mathrm{CFU} . \mathrm{ml}^{-}$ ${ }^{1}$ of the pathogenic $V$. nigripulchritudo strain. This density was shown in preliminary experiments to kill approximately half the population within 3 days (Goarant et al., unpub. results). At the end of this challenge, the tanks were emptied in order to remove the waterborne pathogen, and were immediately refilled with clean seawater.

For the susceptibility test 3 tanks each containing 20 shrimps were used for each treatment. Survival was tracked every 6 hours over a 4-day period, as preliminary trials demonstrated that no significant mortality occurred subsequently (Goarant et al., personal communication). For the determination of antioxidant defences and oxidative stress bio indicators following infection, tests were carried out on five replicate tanks per group consisting of 20 shrimps each. Thus two shrimps per tanks were sampled at $0,12 \mathrm{~h}, 24 \mathrm{~h}, 48 \mathrm{~h}$ and $72 \mathrm{~h}$ post infection for subsequent analysis.

\subsection{V. nigripulchritudo prevalence and load in haemolymph}

The haemolymph was collected individually from the ventral-sinus cavity (venous blood), using a $1 \mathrm{ml}$ sterile needle and syringe, after rinsing the shrimps with sterile seawater. Samples were then plated on Marine Agar (w/v) 2\% glycerol added (MAG), on which $\checkmark$. nigripulchritudo colonies produce a grey to black pigment [27]. Putative $V$. nigripulchritudo colonies were counted and recorded for each animal. The prevalence was determined as the percentage of animals presenting at least one $V$. nigripulchritudo colony, and the load as the number of such colonies recorded per infected animal.

\subsection{Measurement of oxidative stress parameters}

\section{Sampling and conservation}

Haemolymph $(100 \mu \mathrm{l})$ was withdrawn from the ventral sinus cavity of individual shrimps. The samples were collected using a 23-gauge needle and $1 \mathrm{ml}$ syringe. Then $25 \mu \mathrm{l}$ haemolymph samples were immediately diluted in $25 \mu \mathrm{l}$ pre-cooled trisodium citrate buffer $30 \mathrm{mM}, 0.34 \mathrm{M}$ sodium chloride, $1 \mathrm{mM}$ EDTA. Sampl

es were then immediately frozen and stored at $-80^{\circ} \mathrm{C}$ until assays were conducted.

The digestive gland was removed and immediately frozen in liquid nitrogen and stored at $80^{\circ} \mathrm{C}$. For the assay, the organ was defrosted, divided into two parts, and each part was weighed. One part was homogenized in $4 \mathrm{ml}$ Tris buffer $10 \mathrm{mM}, 1 \mathrm{mM}$ DTPA, $1 \mathrm{mM}$ PMSF, $\mathrm{pH} 7.4$ and the other part in $4 \mathrm{ml}$ trisodium citrate buffer $30 \mathrm{mM}, 0.34 \mathrm{M}$ sodium chloride, 1 mM EDTA specifically for Total Antioxidant Status (TAS) determination.

The diluted haemolymph and digestive gland homogenates were centrifuged at $4000 \mathrm{rpm}$ for 10 min at $4^{\circ} \mathrm{C}$ and the supernatants kept at $-80^{\circ} \mathrm{C}$ until used for the analysis. For glutathione assays, the supernatants were neutralised with $6 \%$ metaphosphoric acid before storing.

\section{Biochemical analysis}

All the parameters were determined by biochemical assays with the microplate reader Synergy HT (Bioteck®) as previously described [24] (Castex et al., 2009). 
Total SOD activity was assayed following the method of Marklund and Marklund (1974) [28] based on the auto-oxidation of pyrogallol. CAT activity was measured following the reduction of $\mathrm{H}_{2} \mathrm{O}_{2}$ at 240nm according to Clairbone et al. (1985) [29]. Gpx activity was assayed following the rate of NADPH oxidation by the coupled reaction with glutathione reductase at $340 \mathrm{~nm}$ according to Günzler and Flohé (1985) [30]. The soluble protein content was determined by the Folin phenol method according to Lowry et al. (1951) [31]. All enzymatic units were expressed as specific activities (U.mg of protein ${ }^{-1}$ ). Glutathione levels (reduced (GSH) and oxidized (GSSG) forms) was determined spectrophotometrically using 5,5-dithio2-nitrobenzoic acid according to Akerboom and Sies (1981) [32], and the GSSG/GSH ratio, a valuable biomarker of oxidative stress, positively correlated with oxidative stress level was systematically calculated.

TAS was determined using the Randox Kit, referred to as the "Total Antioxidant Status Kit" (Randox Co., Antrim, UK). As an index of lipid peroxidation we used the formation of TBARS during an acid-heating reaction [33]. Results were expressed as malondialdehyde (MDA) equivalents (nmol.mg prot ${ }^{-1}$ ). Crabonyl protein content was measured according to Levine et al. (1994) [34] with 2,4-dinitrophenylhydrazine (DNTP).

For all the parameters, relative values were calculated for each tank as the ratio of the value of the parameter for infected shrimps (control and probiotic) to that of uninfected shrimps (by using mean value of control for each sample time): Relative $\mathrm{X}_{\mathrm{i}, \mathrm{i}}=\mathrm{X}_{\mathrm{i}, \mathrm{l}} /\left(\bar{X}_{\text {control, } \mathrm{i}}\right)$ where $\mathrm{i}=\mathrm{c}, \mathrm{p}$ (for control infected and probiotic infected) and $\mathrm{j}=0,12,24,48$ and $72 \mathrm{~h}$.

All the biomarkers were measured in the digestive gland, while TAS was also measured in the haemolymph. The reasons to do so are the following: (i) First, in marine aquatic organisms, it has been reported that the main antioxidant enzymes are generally with higher activity in biotransformation organs as digestive tissues (Livingstone et al., 1992) [35]. Furthermore, a preliminary trial carried out in our laboratory under the same conditions as the present study (unpub. results), as well as results from a previous study [24] confirmed this observation and showed that antioxidant status parameters in the digestive gland were sensitive biomarkers of bacterial infection. (ii) Furthermore in the haemolymp, TAS has been found to be a valuable and integrative biomarker of oxidative stress in shrimps [24, 36] (Lemaire and Chim, 2007). Indeed TAS is a quantitative measurement which represents the total contribution from a wide range of antioxidant molecules [37]. (iii) Finally, from a statistical point of view, coefficients of variation of the biochemical parameters have been found to be much more variable in the haemolymph than in the digestive gland, except for TAS (24); then based on the experimental design, the parameters to be analysed were selected after power calculation analyses.

\subsection{Statistical analysis}

All the data in figures and table are presented as means \pm standard deviations of 5 tanks. The data were statistically analysed by the statistical package StatView (SAS Inc., Cary, NC, USA). Survival rates were compared with a "Chi-square" test. For each biochemical parameter, a two-way ANOVA was conducted to assess the effect of time post-infection, treatment and the interaction of the two. Pairwise comparisons were obtained using Fisher's Protected Least Significant Difference (PLSD) to determine differences between treatments.

\section{Results}

During the month of impregnation, the shrimps grew well and no particular mortality was recorded in either group. Transfer of the shrimps to the experimental room did not induce any mortality and after 6 days the shrimps had recovered well from the transfer. At that time all the feed provided ( $2 \% \mathrm{BM})$ was consumed by the shrimps. 


\subsection{V. nigripulchritudo prevalence and Shrimp mortality}

First, the haemolymph of the shrimps before infection was found to be free from $V$. nigripulchritudo strains. Immersion with $V$. nigripulchritudo SFn1 for two hours resulted in infection of the shrimps, showing maximal prevalence values at 12 hours post infection (h.p.i.) (Figure 1). Prevalence stayed at a maximum level until 24 h.p.i and then steadily decreased to reach low or null values at 72 hours. Whatever the treatment, prevalence reached the same maximum level at 12 h.p.i.. However, beyond that time, prevalence of shrimps from the probiotic group was systematically lower than the control. The decrease in prevalence in the probiotic-fed shrimps was found to start at 24 h.p.i., before the control shrimps. Moreover the $V$. nigripulchritudo load peaked at 24 h.p.i. and decreased thereafter to reach almost null values at 72 h.p.i.. At 24 h.p.i. the control group showed more than twice the number of colonies recorded for the probiotic-fed shrimps (Figure 1).

Finally, shrimp mortality started after 24 hours and reached a peak at 48 h.p.i. (Figure 2), whatever the treatment. The number of dead shrimps recovered decreased afterward and ceased at 72 h.p.i.. At the end of the four-day follow-up, the final survival rate in the control infected group was $58.3 \%$, while it was $75.0 \%$ in the probiotic group (fig 2$)(P<0.05)$. The uninfected group did not exhibit any mortalities throughout the trial.

\subsection{Antioxidant defences and oxidative stress}

The results concerning evolutions of the antioxidant defences and "oxidative stress" (OS) parameters following the challenge are presented as relative values calculated in relation to the control uninfected group means for each sample time (Figure 3, 4 \& 5) (see Materials and Methods). The values of each parameter measured at 24, 48 and 72 h.p.i. for the three experimental groups are given in Table 2.

\section{Before infection (b.i.)}

Before infection, shrimps fed the probiotic diet showed higher TAS, SOD and Gpx activities in their digestive gland compared to control (Figure 3\&4), while CAT activity was found to be significantly lower. The oxidative stress level given by the GSSG/GSH ratio was significantly lower in shrimps fed probiotic. In the meantime, the indicators of free radicals damage (MDA and carbonyl protein) were lower in the shrimps fed probiotic, but these differences were not significant. In the blood, the total antioxidant status (TAS) was found to be statistically higher in the probiotic group.

Post-infection (p.i.)

\subsubsection{Control infected shrimps}

Statistical analysis showed that infection by $V$. nigripulchritudo SFn1 induced significant variations within 72 hours in all the parameters measured (Table 1).

General trends in the control infected group indicated that, in the digestive gland, antioxidant defences decreased significantly following infection (Figure 3 and 4), while oxidative stress level (GSSG/GSH) and tissue damage (MDA and carbonyl protein) increased (Figure 5). These changes systematically occurred from 24 or 48 h.p.i..

Antioxidant defences expressed as relative TAS, and SOD, CAT and Gpx activities decreased at 24 h.p.i. (Figure 3\&4). Moreover, before that decrease relative TAS and CAT activity in the digestive gland were found to significantly increase at 12 h.p.i. (Figure 3 and 4). 
The values measured for each of the antioxidant defences parameters were significantly lower in infected group compared to the uninfected one at 24 h.p.i. and/or at 48 h.p.i. (Table 2). Furthermore, at 72 h.p.i. all these parameters returned to initial levels and no significant difference from the uninfected group was subsequently detected (Table 2).

Tissue damage and OS level, measured here with the GSSG/GSH ratio, MDA and carbonyl protein in the digestive gland, increased significantly after infection. Indeed, GSSG/GSH ratio and carbonyl protein content in the digestive gland showed an increase in their relative values (Figure 5) and significant higher levels compared to those recorded in the uninfected group at 24 h.p.i. and 48 h.p.i. (Table 2). Relative MDA also increased at 24 h.p.i. but significantly decreased at 48 h.p.i., to increase again at 72 h.p.i.. The infected group exhibited significantly higher MDA levels at 24 and 72 h.p.i. and a significantly lower level at 48 h.p.i.. At 72 h.p.i. the GSSG/GSH ratio and carbonyl protein decreased slightly but remained significantly higher compared to the uninfected group (Table 2).

In the haemolymph, TAS was found to start decreasing at 12 h.p.i. to reach a minimum level at 24 h.p.i. and then recovered its initial level at 72 h.p.i (Fig 3a).

\subsubsection{Probiotic infected compared to control infected shrimps}

In the probiotic infected group, the antioxidant defences and OS parameters were only slightly affected by the infection. Indeed in this group, relative values of the parameters did not systematically change over time, contrary to what was described for the infected control group (Table 1).

In the digestive gland, in regard to antioxidant defences, relative TAS and SOD and CAT activities did not decrease in the probiotic group over the 72-hour period (Figure 3\&4), as shown by the absence of any significant time effect in this group (Table 1). However, relative Gpx activity changed significantly over the course of the trial, but the time*treatment interaction indicated that the variations of this parameter were different compared to control infected shrimps (Figure 4). Indeed Gpx activity in the probiotic group was found to significantly rise at 48 h.p.i. and to decrease later than in the control group (at 72 h.p.i.). All other parameters studied evolved in the same way as observed for the control infected group, except CAT activities which remained stable (Figure 4).

At 24 and 48 h.p.i., significant differences between both probiotic and control infected groups were systematically detected for all measured antioxidant defences parameters exept for relative CAT activities (Table 2). Moreover, the probiotic treatment was found to have a significant effect (treatment and time*treatment effect) on all the parameters measured (Table 1). Relative TAS value at 24 h.p.i., and SOD and Gpx activities at 24 h.p.i. and 48 h.p.i. were significantly higher in the probiotic group compared to control.

Relative GSSG/GSH, MDA and carbonyl protein were significantly lower in the probiotic group compared to the infected control at 24 h.p.i. Furthermore, these differences were still significant at 48 h.p.i. for the GSSG/GSH ratio and at 48 and 72 h.p.i. for carbonyl protein.

Finally, in the haemolymph, TAS was found to follow the same trend as for control infected shrimps but its levels were significantly higher at 12, 24 and 48 h.p.i. (Figure 3).

\subsubsection{Probiotic infected compared to control uninfected shrimps}

Only small differences were detected between the probiotic infected and uninfected groups: SOD and CAT activities in the probiotic infected group showed respectively higher and lower values at 24 h.p.i. (Table 2), while the MDA level in this group was significantly lower at 48 h.p.i.. At 72 h.p.i. no statistical difference was detected between the probiotic infected and the uninfected groups whatever the parameter (Table 2). 


\section{Discussion}

Our study showed that infection by 2 hour-immersion with $V$. nigripulchritudo at $10^{5}$ CFU.ml ${ }^{-1}$ led to $41.7 \%$ mortality with a peak at 48 hours post-infection (p.i.). These results are in agreement with previous studies carried out in our laboratory (Goarant et al., unpub. results). Indeed, $10^{5}$ CFU. $\left.\right|^{-1}$ was previously determined as the $50 \%$ lethal dose for V. nigripulchritudo SFn1 in Litopenaeus stylirostris. Moreover, our results showed that the increase in prevalence and the load of the pathogenic strain in the haemolymph were maximal at 24 h.p.i., hence prior to the mortality peak recorded at 48 hours. This result is in agreement with previous observations with shrimps reared in ponds affected by $V$. nigripulchritudo [4, 38]. Indeed Goarant et al. (2006) [4] suggested the existence of a latency phase in the "summer syndrome" disease due to V. nigripulchritudo; the delay between maximal infection level and highest mortality may being due to the virulence characteristics of this strain [39].

In the present study, the mortality of the shrimps challenged with $V$. nigripulchritudo was reduced from $41.7 \%$ to $25 \%$ when fed $P$. acidilactici. Several studies have reported increased resistance of shrimps to pathogenic Vibrio through probiotic administration [40, 41]. Chiu et al. (2007) [22] even reported a similar survival improvement with probiotic Lactobacillus plantarum given at $10^{7} \mathrm{CFU} . g^{-1}$ to $L$. vannamei challenged with $\mathrm{V}$. alginolyticus. Moreover, our result confirmed previous findings which have shown that $P$. acidilactici increased the final survival rate of $L$. stylirostris when infection by $V$. nigripulchritudo occurred in commercial ponds or in experimental tanks [42]. Furthermore, in the haemolymph of the shrimps fed probiotic, lower prevalence and load of $V$. nigripulchritudo were recorded, especially at 24 h.p.i., when their levels were maximum in the control infected group. These results suggest a lower infection level of the shrimps fed $P$. acidilactici and may account for the reduced mortality recorded in the probiotic group.

In shrimp, the various natural routes of infection by virulent bacterial isolates are theoretically oral, trans-cuticular or caused by wounds, through an imbalance in the natural bacterial flora, or by vertical transmission of the pathogen [26]. The natural route of infection for $V$. nigripulchritudo has not yet been studied and merits future consideration. However, histopathological studies of infected shrimp with vibriosis strongly suggest an oral infection route, even though description of the process of gut colonization in vivo has not been undertaken $[43,44]$. In this study we preferred the immersion route of infection, since it is probably closer to the natural source of virulent bacterial strains, as suggested by a number of studies [43, 45, 46, 47, 48]. However, most of the studies carried out on the physiological and immune response of shrimps following bacterial challenge used injection [18, 20]. Moreover, studies on the effect of probiotics using disease challenges with infection by injection override one of the possible methods of probiotic protection against pathogens by masking the potential effect of probiotic competitive exclusion within the gastro intestinal tract. Gastric probiotics may reduce or prevent gastric infection and infection challenges may not reflect the effect of probiotics on resistance to infection.

\subsection{Infection and antioxidant defences}

The antioxidant defence system and the immune system are closely linked in the response to pathogens [12]. Moreover, the integrated antioxidant system is recognised as an essential component of an organism's self-maintenance. Therefore the implication of the antioxidant defence system in the development of disease through its ability to limit "oxidative stress" (OS) induced by respiratory burst activity and/or metabolism disturbances, even if poorly investigated in shrimp, may be of crucial importance [15]. Recent studies carried out with shrimps have shown that bacterial infection leads to respiratory burst $[9,20]$ and modifications in antioxidant enzyme activities and their gene expressions $[16,17,18,20]$. For instance, infection by $V$. alginolyticus pathogenic strains has been reported to result in 
increased levels of superoxide anion and decreased SOD activities in the haemolymph of $L$. vannamei and $F$. indicus from 12 hours p.i. $[16,17]$. Those results showed that even if a small increase in superoxide anion is considered to be beneficial for enhancing immunity [9], too great an increase may have adverse effects [49]. However, those studies did not report results concerning other antioxidant defences, and generally focused on the characterisation of the immune response, thereby making comparisons with our study difficult.

Our results clearly showed that bacterial infection induces the mobilisation of the antioxidant defence system and the OS development leading to oxidative damages to tissue from 24 h.p.i.. Recent work on viral infection also has clearly demonstrated the OS development within a few hours after infection [14, 15]. Thus Mathew et al. (2007) [15] reported a concomitant increase in lipid peroxidation and a drop in antioxidant enzyme activities of SOD, CAT, Gpx and Glutathion-S- transferase in the digestive gland, muscle and haemolymph of $P$. monodon following infection with white spot syndrome virus (WSSV). They conclude that the antioxidant defence system was affected by the viral infection and that tissue antioxidant status was operating at a very much lower rate in $P$. monodon despite the higher requirement for dismutation of harmful radical formation during WSSV infection. Interestingly, their results showed that this phenomenon was detected from 24 h.p.i., as observed in our study. Moreover, Sarathi et al. (2007) [16] compared immune response of Fenneropenaeus. indicus to bacterial and viral infection and showed that the innate immune system responded similarly against both pathogens with lowered THC, SOD activity, clotting time and increase accumulation of haemocytes at the site of injection, prophenoloxidase activity and superoxide anion levels. Thus our results are in agreement with these studies. The decrease in the antioxidant defences of $L$. Stylirostris recorded here probably led to an accumulation of free radicals such as hydrogen peroxide and the hydroxyl radical which may have caused tissue damages. To our knowledge, this study is the first to report such a phenomenon in shrimps infected by immersion with pathogenic bacteria. Interestingly, the shortage in antioxidant enzymes activities (SOD, CAT and Gpx) and overall antioxidant defences (TAS) and the increase in OS level and tissue damage appeared when the prevalence and load of $V$. nigripulchritudo were maximal in the haemolymph. This may indicate an enhanced immune response and/or a metabolism stimulation leading to an excessive production of ROS at that time. It is also interesting to note that relative CAT activity and relative TAS values in the digestive gland showed an increase at 12 h.p.i. in the infected control group before falling at 24 h.p.i. This might be an attempt at counteraction or neutralisation of the harmful free radicals generated due to bacterial infection, as previously suggested [15]. Moreover we showed a significant reduction in the relative activity of glutathione peroxidase in the vibrio infected group. In addition, the levels of GSH and GSSG were respectively significantly reduced and increased. The decline in the Gpx activity at 24 h.p.i. may have made cellular and subcellular membranes more sensitive to oxidative damage and may explain the increase in relative MDA and carbonyl protein levels at that time. Indeed, the decrease in relative Gpx activity, concomitant to the decrease in CAT and SOD activity, may have led to an accumulation of hydrogen peroxide, which in turn may have formed hydroxyl radicals and brought about a number of harmful reactions to cells.

Lipid peroxidation is one of the major problems associated with failure of the antioxidant system. In this study we determined the Malondialdehyde level (MDA), a secondary product of lipid peroxydation, frequently used as a biomarker of oxidative damage to lipids [50]. We also looked at the damaged protein by measuring the carbonyl protein content. Indeed, the highly reactive hydroxyl radical $(\mathrm{OH})$, which is generated in the process leading to oxidative stress, is considered to be responsible for the formation of carbonyl groups in protein [51]. We found evidence of oxidative damage as indicated by increased MDA and carbonyl proteins in the digestive gland of the infected shrimps. Interestingly, we showed that relative carbonyl protein values increased with increased oxidative stress level, evidenced by the rise in the GSSG/GSH ratio. However, the drop in MDA level at 48 h.p.i. measured in this study remains difficult to explain. MDA and lipid peroxides are themselves free radicals with large reaction constants which lead to oxidative damage, as modifications of proteins such as protein carbonylation. Thus it is possible that the increase in MDA level at 24 h.p.i. might 
have enhanced a system for the detoxification of lipid hydroperoxides. The determination of the glutathione S-transferase activity, an enzyme involved in the detoxification of lipid hydroperoxides, would have been useful to strengthen this hypothesis.

Finally, at 72 h.p.i. the shrimps recovered and antioxidant defences returned to initial levels. This indicates that shrimps recovered from the infection, which is in agreement with the results of Sarathi et al. (2007) [16], who showed that the shrimp innate immune system raised against bacterial infection returned to a normal level after recovery from Vibriosis, whereas this was not the case in WSSV infected shrimps. However, the MDA and carbonyl protein content in the digestive gland were still higher at 72 h.p.i. in the infected group compared to the uninfected one. This might be due to the time needed to detoxify oxidized compounds [52].

\subsection{Effect of probiotic on the response to infection}

In regard to the probiotic effect, our results showed that the infected shrimps previously fed with the probiotic enriched diet maintained the levels of their antioxidant defences compared to the control over the 72-hour challenge period. Indeed, TAS and SOD, Gpx and CAT activities in the digestive gland did not decrease after infection as observed in the control group. Only Gpx activity showed a decrease at 72 h.p.i., reaching a similar value to the control infected and uninfected shrimps. By contrast, CAT activity was significantly lower in the probiotic group before infection compared to the control. This lower level of CAT in the probiotic group remained until 12 h.p.i. and 24 h.p.i. compared to the infected and the uninfected groups respectively. This result is difficult to explain, but might be due to lower free radical generation in the probiotic-fed shrimps under normal conditions or to the use of other antioxidant pathways to scavenge them. The higher TAS values recorded in the haemolymph of the probiotic shrimps compared to control before the infection, and until 12 h.p.i. may be consistent with this hypothesis. Moreover the higher TAS in the haemolymph and digestive gland of $L$. stylirostris fed probiotic $P$. acidilactici for one month confirm our previous results [24]. Interestingly several works reported that Lactic Acid Bacteria (LAB) have antioxidant activities [53] and some studies showed an enhancement of total antioxidant status (TAS) in blood of humans fed LABs [54]. The TAS level in the haemolymph of the probiotic-fed shrimps decreased from 12 h.p.i. as observed for the control animals. However, this drop was lower and TAS remained significantly higher up to 48 hours before finally showing similar levels to control animals at 72 h.p.i. This result suggests that the probiotic confers a higher antioxidant capacity on the shrimp to cope with the respiratory burst and/or the alteration of metabolism induced by the infection. Consequently, tissue damages and the OS level induced by the infection were lowered in the probiotic group compared to the control. Indeed, significant lower relative MDA, carbonyl protein and GSSG/GSH ratio were observed at 24 h.p.i. in the probiotic group. Furthermore, the post infection evolution of the antioxidant defences and oxidative stress level in the probiotic group only showed slight differences from the uninfected group, suggesting that the shrimp fed probiotics were able to cope efficiently with the infection and therefore to limit associated damage.

All these results lead to three explanatory hypotheses on to the probiotic action and would merit to be investigates in the future: (i) the probiotic may have in some way taken part into the limitation of the infection by $V$. nigripulchritudo resulting in a lower immune response and then a lower respiratory burst and associated OS response, or (ii) the probiotic may have contributed to increase the overall physiological status of the shrimps, including antioxidant status and immune response, resulting in a higher elimination of the pathogen via an increased respiratory burst and lower ROS-induced damage through higher antioxidant defences, and finally (iii) the probiotic may have lowered the metabolic stress induced by pathogen infection. Indeed, the inner membrane of mitochondria is the primary site of ROS production and reduced cellular oxygen levels during stress can enhance mitochondrial production of ROS [7]. According to these hypotheses, the observed decrease in the 
prevalence and load of the Vibrio in the haemolymph of the probiotic-fed shrimps might be either a cause or a consequence of the probiotic effect.

In regard to the first hypothesis, several studies have reported in vitro antibacterial activity of probiotic strains in relation to bacterial pathogens in shrimp [55]. Others have shown competitive exclusion or in vivo antagonism on the shrimp microbiota $[38,56]$. It is generally suggested that probiotic might be able to prevent and/or limit bacterial infection by competitive exclusion, depending on the production of inhibitory compounds or competition for adhesion sites, energy and/or nutrients [57]. Competitive exclusion is an action mechanism widely invoked in the literature, but the ways in which this mechanism operates have been insufficiently investigated in shrimp studies. For instance, Chythanya et al. (2002) [55] reported the inhibitory activity of cell free extract of $P$. aeruginosa $I 2$ and showed that the extract was able to level off $V$. harveyi concentration in water by over a log unit when applied at $20 \mathrm{mg} / \mathrm{ml}$. This effect was associated with the inhibitory effect of the chloroform extract of Pseudomonas I-2 cell free supernatant, and the author suggested that Pyocyanine could be the antibacterial principle responsible for the inhibition of the Vibrio. In their study, Gullian et al. (2004) [56] showed colonisation of the digestive gland of $P$. vannamei by several probiotic strains and highlighted competitive interaction of these strains with the pathogenic $V$. harveyi strain using RAPDs and monoclonal antibodies. They reported that the probiotic strain Vibrio P62 was able to reduce the colonization of $V$. harveyi S2 by $60 \%$, as well as displacing the indigenous micro flora in the digestive gland. Interestingly, we previously reported the in vivo antagonism effect of $P$. acidilactici on shrimp microbiota $[38,42]$ and the in vitro effect of $P$. acidilactici on $V$. nigripulchritudo has also been shown elsewhere [58]. However, the characterisation of the infection route of $V$. nigripulchritudo would be necessary prior to stating whether the effect of the probiotic in the digestive tract could allow a limitation of the infection.

In regard to the second hypothesis, several authors have reported the effect of probiotics on shrimp immunity [59, 56 38, 60]. For instance, Rengpipat et al. (2000) [59] showed, in $P$. monodon fed Bacillus S11, an enhancement of the cellular and humoral defence mechanisms with increases in the total Haemocyte count (THC), the phagocytic index and the antibacterial activity in the haemolymph. Li (2008) [61] recently reported immunity enhancement

of L. vannamei infected with pathogenic Vibrio and fed probiotic bacterium Arthrobacter XE-7. These authors showed increased THC, phenoloxidase activity, respiratory burst and percentage phagocytosis in the probiotic-fed shrimps. Recently, Chiu et al. (2007) [22] reported that Lactobacillus plantarum administered at $10^{7} \mathrm{CFU} \cdot \mathrm{g}^{-1}$ of feed was able to induce immune modulation and enhanced immunity ability of $L$. vannamei, increasing its resistance to $V$. alginolyticus infection. Indeed, these authors showed enhanced cellular and humoral responses such as phenoloxidase activity, superoxidase activity, clearance efficiency against $V$. alginiolyticus, and proPO and peroxinectin (PE) mRNA transcription levels in the probioticfed shrimps. Interestingly, they showed that when probiotic was added, the respiratory burst in the shrimps' haemolymph were reduced through increase in SOD and PE gene transcription and suggested that $L$. plantarum may enhance antioxidant status of the shrimp concomitantly to increasing in the immune response. At this stage, similar studies on the effect of $P$. acidilactici on the shrimp immune system and antibacterial activity in the haemolymph would be useful to assess this second hypothesis.

Finally, both hypotheses, competitive exclusion with pathogen and increase in immune ability and antioxidant status of the host, might be also involved simultaneouslyc. Indeed, Li (2008) [61] recently showed the positive effect of the probiotic bacteria Arthrobacter XE-7 on the resistance of juvenile $L$. vannamei challenged with Vibrio parahaemolyticus and concluded that there was competitive exclusion of the pathogen establishment inside the host and a conferred immunostimulation by the probiotic.

With respect to the third hypothesis our investigations remain at a very early stage. However we can say that we have shown elsewhere [42] that feed requirement for maintenance metabolism was lower to some extend in juvenile shrimps fed with the same probiotic diet compared to control. This lower maintenance metabolism means a lower oxygen 
requirement of the tissue and could traduce therefore a lower susceptibility of hypoxia leading to mitochondrial overproduction of ROS [7].

\section{Conclusion}

In conclusion, the results of the present investigation indicate that infection by a pathogenic Vibrio produces significant alterations in the antioxidant defence system and results in increased oxidative stress in $L$. stylirostris. Dietary supplementation with $P$. acidilactici at $10^{7}$ CFU. $\mathrm{g}^{-1}$ for one month prior to the challenge allowed these adverse effects to be reduced and conferred better resistance of the shrimps to $V$. nigripulchritudo. Further investigations are of course necessary to elucidate which of the hypothesis arose would be in fact validated.

\section{Acknowledgments}

We thank the technical staff of the experimental facilities at St Vincent, New Caledonia for their help. 


\section{References}

[1] Bachère, E. Shrimp immunity and disease control. Aquaculture 2000; 191: 3-11.

[2] Lightner, D.V., Redman, R.M. Strategies for the control of viral disease of shrimp in the Americas. Fish Pathology 1998; 33:165-180.

[3] Le Groumellec, M., Goarant, C., Haffner, P., Berthe, F., Costa, R., Mermoud, I.,. Syndrome 93 in New Caledonia: Investigation of the bacterial hypothesis by experimental infections, with reference to stress-induced mortality. SICCPPS book of abstracts, SEAFDEC, lloilo City, Philippines, 1996; p. 46.

[4] Goarant, C., Ansquer, D., Herlin, J., Domalain, D., Imbert, F., De Decker, S. Summer Syndrome in Litopenaeus stylirostris in New Caledonia: Pathology and epidemiology of the etiological agent, Vibrio nigripulchritudo. Aquaculture 2006; 253: 105-113.

[5] Wang, Y.B., Li, J.R., Lin, J. Probiotics in aquaculture: Challenges and outlook. Aquaculture 2008; 281: 1-4.

[6] Livingstone, D.R. Contaminant-stimulated reactive oxygen species production and oxidative damage in aquatic organisms. Mar. Pollut. Bull. 2001; 42: 656-666.

[7] Kassahn, K.S., Crozier, R.H., Pörtner, H.O., Caley, M.J. Animal performance and stress: responses and tolerance limits at different levels of biological organisation. Biol. Rev. 2009; 84: 277-292.

[8] Halliwell, B., Gutteridge, J.M.C. Free Radicals in Biology and Medicine, 3rd ed. Oxford University Press, 1999.

[9] Muñoz, M., Cedeño, R., Rodríguez, J., Van der Knap, W.P.W., Mialhe, E., Bachère, $\mathrm{E}$. Measurement of reactive oxygen intermediate production in haemocytes of the penaeid shrimp, Penaeus vannamei. Aquaculture 2000; 191: 89-107.

[10] Söderhäll, K., Cerenius, L. Role of the prophenoloxidase-activating system in invertebrate immunity. Current Opinion in Immunology 1998; $10: 23-28$.

[11] Le Moullac, G., Soyez, C., Saulnier, D., Ansquer, D., Avarre, J.C., Levy, P. Effect of hypoxic stress on the immune response and the resistance to vibriosis of the shrimp Penaeus stylirostris. Fish Shellfish Immunol. 1998; 8: 621-629.

[12] Holmblad, T., Söderhäll, K. Cell adhesion molecules and antioxidative enzymes in a crustacean, possible role in immunity. Aquaculture 1999; 172: 111-123.

[13] Li, E., Chen, L., Zeng, C., Yu, N., Xiong, Z., Chen, X., Qin, J.G. Comparison of digestive and antioxidant enzymes activities, haemolymph oxyhemocyanin contents and hepatopancreas histology of white shrimp, Litopenaeus vannamei, at various salinities. Aquaculture 2008; 274: 80-86.

[14] Rameshthangam, P., Ramasamy, P. Antioxidant and membrane bound enzymes activity in WSSV-infected Penaeus monodon Fabricius. Aquaculture 2006; 254: 32-39.

[15] Mathew, S., Kumar, K.A., Anandan, R., Nair, P.G.V., Devadasan, K. Changes in tissue defence system in white spot syndrome virus (WSSV) infected Penaeus monodon. Comparative Biochemistry and Physiology, Part C 2007; 145: 315-320.

[16] Sarathi, M., Ahmed, V.P. I., Venkatesan, C., Balasubramanian G.,Prabavathy, J., Hameed, A.S.S. Comparative study on immune response of Fenneropenaeus indicus to Vibrio alginolyticus and white spot syndrome virus. Aquaculture 2007; 27: 8-20.

[17] Hsieh, S-H., Ruan, Y-H., Li, Y-C., Hsieh, P-S., Hu, C-H., Kuo, C-M. Immune and physiological responses in Pacific white shrimp (Penaeus vannamei) to Vibrio alginolyticus. Aquaculture 2008; 275: 335-341.

[18] Li, C.C., Yeh, S.T., Chen, J.C. The immune response of white shrimp Litopenaeus vannamei following Vibrio alginolyticus injection, Fish and Shellfish Immunology 2008; doi: 10.1016/j.fsi.2008.09.014.

[19] Gómez-Anduro, G., Barillas-Mury, C.V., Peregrino-Uriarte, A.B., Gupta, L., GollasGalván, T., Hernández-López, J., Yepiz-Plascencia, G. The cytosolic manganese superoxide dismutase from the shrimp Litopenaeus vannamei: Molecular cloning and expression. Developmental and Comparative Immunology 2006; 30: 893-900. 
[20] Liu, C.H., Tseng, M.C., Cheng, W. Identification and cloning of the antioxidant enzyme, glutathione peroxidase, of white shrimp, Litopenaeus vannamei, and its expression following Vibrio alginolyticus infection. Fish \& Shellfish Immunology 2007; 23: 34-45.

[21] Zhang, O., Li, F., Zhang, X., Dong, B., Zhang, J., Xie, Y., Xiang, J. cDNA cloning, characterization and expression analysis of the antioxidant enzyme gene, catalase, of Chinese shrimp Fenneropenaeus chinensis. Fish \& Shellfish Immunology 2008; 24: 584-591. [22] Chiu, C.H., Guu, Y.K., Liu, C.H., Pan, T.M., Cheng, W. Immune responses and gene expression in white shrimp, Litopenaeus vannamei, induced by Lactobacillus plantarum. Fish \& Shellfish Immunology 2007; 23: 364-377.

[23] Hsieh, T.J.., Wang J-C., Hu, C.Y., Li, C.T., Kuo, C.M., Hsieh, S-L. Effects of Rutin from Toona sinensis on the immune and physiological responses of white shrimp (Litopenaeus vannamei) under Vibrio alginolyticus challenge. Fish \& Shellfish Immunology 2008; 25: 581-588.

[24] Castex, M., Lemaire, P., Wabete, N., Chim, L. Effect of dietary probiotic Pediococcus acidilactici on antioxidant defences and oxidative stress status of shrimp Litopenaeus stylirostris. Aquaculture 2009; $294:$ 306-313.

[25] Wabete N., Chim, L., Pham, D., Lemaire, P., Massabuau, J.C. A soft technology to improve survival and reproductive performance of Litopenaeus stylirostris by counterbalancing physiological disturbances associated with handling stress. Aquaculture 2006; 260: 181-193.

[26] Saulnier, D., Haffner, P., Goarant, C., Levy, P., Ansquer, D. Experimental infection models for shrimp vibriosis studies: a review. Aquaculture 2000; 191: 133-144.

[27] Baumann, P., Schubert, R.H.W. Section 5. Facultatively anaerobic Gram-negative rods, Family II. Vibrionaceae. In: Holt, J.G., Krieg, N.R. (Eds.), Bergey's Manual of Systematic Bacteriology, vol. 1. Williams \& Wilkins Co., Baltimore, MD, 1984; pp. 516-550.

[28] Marklund, S., and Marklund, G. Involvement of superoxide anion radical in the auto oxidation of pyrogallol and a convenient assay for superoxide dismutase, European Journal of Biochemistry 1974; 47: 469-474.

[29] Clairbone, A. Catalase. In: R. Greenwald, Editor, Handbook of Methods for Oxygen Radical Research, CRC Press, New York 1985; pp. 283-284.

[30] Günzler, A., and Flohé, L. Glutathione peroxidase. In: R.A. Greenwald, Editor, CRC handbook of methods for oxygen radical research (Vol. 1), CRC Press, Boca Raton, Florida, USA 1985; pp. 285-290.

[31] Lowry O., Rosebrough, N.J., Farr, AL., Randall, R.S. Protein measurements with Folin phenol reagent. J. Biol. Chem. 1951; 193, 265-275.

[32] Akerboom, T.P.M., and Sies, H. Assay of glutathione, glutathione disulfide and glutathione mixed disulphides in biological samples. Methods Enzymol 1981; 77: 373-382.

[33] Draper, H.H., Hadley M. Malondialdehyde determination as an index of lipid peroxidation. Methods Enzymol 1990; 186: 421-431.

[34] Levine, R.L.,Williams, J.A., Stadman, E.R., Shacther, E. Carbonyl assays for determination of oxidatively modified proteins. Methods in Enzymology, 233, Academic Press, New York, 1994; pp. 346-357.

[35] Livingstone, D.R., Lips, F., Garcia Martinez, P., Pipie, R.K., 1992. Antioxidant enzymes in

digestive gland of the common mussel, Mytilus edulis L. Mar. Biol. 112, 265-276.

[36] Lemaire, P., Chim, L., 2007. Effect of experimental temperature fluctuations on some "oxidative stress" bio-indicators in the digestive gland of the shrimp Litopenaeus stylirostris. Annual Meeting, 9-13 May 2007, Mexico.

[37] Prior, R.L., Cao, G., 1999. In vivo total antioxidant capacity: comparison of different analytical methods. Free Radic. Biol. Med. 27, 1173-1181.

[38] Castex, M., Chim, L., Pham, D., Lemaire, P., Wabete, N., Nicolas, J.-L., Schmidely, Ph., Mariojouls, C. Probiotic P. acidilactici application in shrimp Litopenaeus stylirostris culture subject to vibriosis in New Caledonia. Aquaculture 2008; 275: 182-193.

[39] Reynaud, Y. Identification de marqueurs génétiques de la virulence chez Vibrio nigripulchritudo, un pathogène de crevettes pénéides en Nouvelle-Calédonie. Thesis 
presented at l'Université Paris 6 - Pierre et Marie Curie, Ecole doctorale Ecole Doctorale B2M - Biochimie et Biologie Moléculaire, 2008 ; 222 pp.

[40] Rengpipat, S., Phianphak, W., Piyatiratitivorakul, S., Menasaveta, P. Effects of a probiotic bacterium in black tiger shrimp Penaeus monodon survival and growth. Aquaculture 1998; 167, 301-313.

[41] Scholz, U., Garcia Diaz, G., Ricque, D., Cruz Suarez, L.E., Vargas Albores, F., Latchford, J., 1999. Enhancement of vibriosis resistance in juvenile Penaeus lannamei by supplementation of diets with different yeast products. Aquaculture 1999; 176: 271-283

[42] Castex, M. Evaluation of probiotic bacteria Pediococcus acidilactici MA18/5 M on penaeid shrimp Litopenaeus stylirostris in New Caledonia. Thesis presented at the "Institut des Sciences et Industries du Vivant et de l'Environnement (Agro Paris Tech)", Ecole doctorale Ecole Doctorale ABIES - Physiology, Nutrition, 2009; 386pp.

[43] Lavilla-Pitogo, C.R., Baticados, M.C.L., Cruz-Lacierda, E.R., de la Peña, L.D. Occurrence of luminous bacterial disease of Penaeus monodon larvae in the Philippines. Aquaculture 1990; 91: 1-13.

[44] Robertson, P.A.W., Calderon, J., Carrera, L., Stark, J.R., Zherdmant, M., Austin, B. Experimental Vibrio harveyi infections in Penaeus vannamei larvae. Dis. Aquat. Org. 1998; 32: 151-155.

[45] Lavilla-Pitogo, C.R., Leano, E.M., Paner, M.G. Mortalities of pond-cultured juvenile shrimp, Penaeus monodon, associated with dominance of luminescent Vibrios in the rearing environment. Aquaculture 1998; 164: 337-349.

[46] De la Peña, L.D., Nakai, T., Muroga, K. Dynamics of Vibrio sp. in organs of orally infected Kuruma prawn, Penaeus japonicus. Fish Pathol. 1995; 30: 39-45.

[47] Lightner, D.V. Shrimp pathology: major diseases of concern to the farming industry in the Americas. Mem. Congr. Ecuat. Acuicult. 1992; 177-195.

[48] Goarant, C., Mérien, F., Berthe, F., Mermoud, I., Pérolat, P. Arbitrarily primed PCR to type Vibrio spp. pathogenic for shrimp. Appl. Environ. Microbiol. 1999; 65: 1145-1151.

[49] Cheng, W., Wang, C.H. The susceptibility of the giant freshwater prawn Macrobrachium rosenbergii to Lactococcus garvieae and its resistance under copper sulfate. Diseases of Aquatic Organisms 2001; 47: 137-144.

[50] Lykkesfeldt, J. Malondialdehyde as biomarker of oxidative damage to lipids caused by smoking. Clinical Chimica Acta 2007; 380: 50-58.

[51] Farber, J.M., Levine, R.L. Sequence of a peptide susceptible to mixed-function oxidation. Probable cation binding site in glutamine synthetase. J. Biol. Chem. 1986; 261: 4574

[52] Ferreira, M., Moradas-Ferreira, P., Reis-Henriques, M.A. Oxidative stress biomarkers in two resident species, mullet (Mugil cephalus) and flounder (Platichthys flesus), from a polluted site in River Douro Estuary, Portugal. Aquatic Toxicology 2005; 71: 39-48.

[53] Kullisaar, T.,, Zilmer, M., Mikelsaar, M., Vihalemm, T., Annuk, H., Kairane, C., Kilk, A. Two antioxidative lactobacilli strains as promising probiotics. International Journal of Food Microbiology 2002; 72: 215-224.

[54] Kullisaar, T., Songisepp, E., Mikelsaar, M., Zilmer, K., Vihalemm ,T., and Zilmer, M. Antioxidative probiotic fermented goats' milk decreases oxidative stress-mediated atherogenicity in human subjects. British Journal of Nutrition 2003; 90: 449-456.

[55] Chythanya, R., Karunasagar, I., Karunasagar, I. Inhibition of shrimp pathogenic vibrios by a marine Pseudomonas I-2 strain. Aquaculture 2002; 208: 1-10.

[56] Gullian, M., Thompson, F., Rodríguez, J. Selection of probiotic bacteria and study of their immunostimulatory effect in Penaeus vannamei. Aquaculture 2004; 233: 1-14.

[57] Vershuere, L., Rombaut, G., Sorgeloos, P., Verstraete, W. Probiotic bacteria as biological control agents in aquaculture. Microbiol. Mol. Biol. Rev. 2000; 64, 655-671.

[58] Reynaud, Y. Utilisation de bactéries probiotiques comme substituts aux antibiotiques, en élevage larvaire de crevette Litopenaeus stylirostris. Mémoire de DEA Océanologie Biologique et Environnement Marin Option Connaissance des Producteurs Primaires, Institut Universitaire Européen de la Mer (IUEM), 2004 ; pp. 34. 
[59] Rengpipat, S., Rukpratanporn, S., Piyatiratitivorakul, S., Menasaveta, P. Immunity enhancement in black tiger shrimp Penaeus monodon by a probiont Bacillus S11. Aquaculture 2000; 191: 271-288

[60] Rodríguez, J., Espinosa, Y., Echeverría, F., Cárdenas, G., Román, R., Stern, S. Exposure to probiotics and $\beta-1,3 / 1,6$-glucans in larviculture modifies the immune response of Penaeus vannamei juveniles and both the survival to White Spot Syndrome Virus challenge and pond culture. Aquaculture $2007 ; 273: 405-415$.

[61] Li, J. Immune Responses and Resistance against Vibrio parahaemolyticus induced by Probiotic Bacterium Arthrobacter XE-7 in Pacific White Shrimp, Litopenaeus vannamei. Journal of the World Aquaculture Society 2008; 39: 477-489.

\section{Tables}

Table 1. Statistical significance of fixed effects (i.e., time post infection and treatment (probiotic vs control infected group)) and the interaction of both fixed effects for each biochemical parameter (relative values were used for the statistical (see Materials \& methods (2.5)) determined, based on type III sum of squares from factorial ANOVA $\left({ }^{*} \mathrm{P}<0.05\right.$, ${ }^{* *} p<0.01,{ }^{* \star *} p<0.005,{ }^{* * * *} p<0.001$ n.s. not significant).

\begin{tabular}{|c|c|c|c|c|c|}
\hline \multirow[t]{2}{*}{ Parameter } & \multicolumn{3}{|l|}{ Effect $^{(1)}$} & \multicolumn{2}{|l|}{ Time effect ${ }^{(2)}$} \\
\hline & Time & Treatment & Time*Treatment & Control infected & Probiotic infected \\
\hline \multicolumn{6}{|l|}{ hemolymph } \\
\hline TAS & 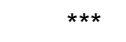 & 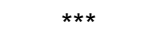 & n.s & ** & * \\
\hline \multicolumn{6}{|l|}{ Digestive gland } \\
\hline TAS & * & n.s & ** & ** & n.s \\
\hline SOD & * & $\star \star$ & ** & ** & n.s \\
\hline CAT & n.s & $\star \star \star ~$ & * & * & n.s \\
\hline GPX & ** & * & * & * & $\star \star$ \\
\hline GSSG/GSH & $\star * \star$ & * & n.s & ** & $\star \star$ \\
\hline MDA & ** & ** & n.s & * & n.s \\
\hline Carbonyl protein & 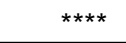 & ** & n.s & * & * \\
\hline
\end{tabular}

(1) Two way analysis of variance

(2) One way analysis of variance 
Table 2. Mean values ( \pm S.D., $n=5$ ) of each antioxidant defences and "oxidative stress" parameter for the uninfected control, and the infected control and probiotic groups after 24, 48 and 72 hours post infection. Comparisons between means were carried out with t-test. Means with different superscript letters within the same line at each sample time were significantly different $(p<0.05)$.

\begin{tabular}{|c|c|c|c|c|c|c|c|c|c|}
\hline Parameters & $\begin{array}{l}24 \text { h.p.i. } \\
\text { Control } \\
\end{array}$ & $\begin{array}{l}\text { Control } \\
\text { infected }\end{array}$ & $\begin{array}{l}\text { Probiotic } \\
\text { infected }\end{array}$ & $\begin{array}{l}48 \text { h.p.i. } \\
\text { Control } \\
\end{array}$ & $\begin{array}{c}\text { Control } \\
\text { infected }\end{array}$ & $\begin{array}{c}\text { Probiotic } \\
\text { infected }\end{array}$ & $\begin{array}{l}72 \text { h.p.i. } \\
\text { Control } \\
\end{array}$ & $\begin{array}{c}\text { Control } \\
\text { infected }\end{array}$ & $\begin{array}{l}\text { Probiotic } \\
\text { infected }\end{array}$ \\
\hline \multicolumn{10}{|l|}{ Hemolymph } \\
\hline TAS $\left(\mu \mathrm{mol} \cdot \mathrm{ml}^{-1}\right)$ & $0.97 \pm 0.15^{\mathrm{a}}$ & $0.26 \pm 0.13^{b}$ & $0.79 \pm 0.10^{\mathrm{a}}$ & $1.05 \mathrm{a} \pm 0.10^{\mathrm{a}}$ & $0.79 b \pm 0.14^{b}$ & $0.99 \pm 0.15^{\mathrm{ab}}$ & $0.90 \pm 0.19^{\mathrm{a}}$ & $0.87 \pm 0.32^{\mathrm{a}}$ & $0.87 \pm 0.31^{\mathrm{a}}$ \\
\hline \multicolumn{10}{|l|}{ Digestive gland } \\
\hline TAS $\left(\mu\right.$ mol.g organ $\left.{ }^{-1}\right)$ & $20.03 \pm 2.52^{\mathrm{a}}$ & $15.36 \pm 0.44^{b}$ & $21.82 \pm 3.13^{\mathrm{a}}$ & $14.56 \pm 3.98^{\mathrm{a}}$ & $14.43 \pm 2.44^{\mathrm{a}}$ & $17.26 \pm 2.74^{\mathrm{a}}$ & $16.53 \pm 2.97^{\mathrm{a}}$ & $20.36 \pm 3.40^{\mathrm{a}}$ & $18.93 \pm 3.49^{\mathrm{a}}$ \\
\hline SOD (U.mg protein $\left.{ }^{-1}\right)$ & $2.00 \pm 0.19^{\mathrm{a}}$ & $1.58 \pm 0.14^{\mathrm{b}}$ & $2.42 \pm 0.22^{\mathrm{C}}$ & $1.46 \pm 0.18^{\mathrm{a}}$ & $0.83 \pm 0.61^{b}$ & $1.67 \pm 0.25^{\mathrm{a}}$ & $1.38 \pm 0.74^{\mathrm{a}}$ & $1.60 \pm 0.35^{\mathrm{a}}$ & $1.37 \pm 0.25^{\mathrm{a}}$ \\
\hline CAT $\left(\mu\right.$ mol. in $^{-1} \cdot$ mg protein $\left.^{-1}\right)$ & $0.36 \pm 014 a$ & $0.33 \pm 0.09^{\mathrm{ab}}$ & $0.21 \pm 0.09^{b}$ & $0.44 \pm 0.07^{\mathrm{a}}$ & $0.31 \pm 0.07^{b}$ & $0.36 \pm 0.07^{\mathrm{ab}}$ & $0.38 \pm 0.13^{\mathrm{a}}$ & $0.36 \pm 0.11^{\mathrm{a}}$ & $0.28 \pm 0.07^{\mathrm{a}}$ \\
\hline GPX $\left(\mathrm{nmol} \cdot \mathrm{min}^{-1} \cdot \mathrm{mg}\right.$ protein $\left.{ }^{-1}\right)$ & $12.14 \pm 1.70^{\mathrm{a}}$ & $9.33 \pm 1.50^{b}$ & $12.17 \pm 0.77^{\mathrm{a}}$ & $13.19 \pm 1.42^{\mathrm{ab}}$ & $11.06 \pm 2.87^{\mathrm{a}}$ & $15.77 \pm 1.79^{b}$ & $15.48 \pm 3.09^{\mathrm{a}}$ & $14.09 \pm 1.81^{\mathrm{a}}$ & $12.75 \pm 2.22^{\mathrm{a}}$ \\
\hline GSSG/GSH & $0.33 \pm 0.04^{\mathrm{a}}$ & $0.46 \pm 0.06^{b}$ & $0.26 \pm 0.04^{\mathrm{a}}$ & $0.25 \pm 0.09^{\mathrm{a}}$ & $0.48 \pm 0.11^{b}$ & $0.33 \pm 0.03^{\mathrm{a}}$ & $0.29 \pm 0.15^{\mathrm{a}}$ & $0.46 \pm 0.16^{b}$ & $0.38 \pm 0.06^{\mathrm{ab}}$ \\
\hline Carbonyl protein (nmol.mg protein ${ }^{-1}$ ) & $0.71 \pm 0.27^{\mathrm{a}}$ & $0.78 \pm 0.20^{\mathrm{a}}$ & $0.57 \pm 0.27^{\mathrm{a}}$ & $0.60 \pm 0.13^{\mathrm{a}}$ & $0.92 \pm 0.18^{b}$ & $0.68 \pm 0.13^{\mathrm{a}}$ & $0.71 \pm 0.18^{\mathrm{a}}$ & $0.91 \pm 0.16^{b}$ & $0.65 \pm 0.09^{\mathrm{a}}$ \\
\hline MDA (nmol.g organ $\left.{ }^{-1}\right)$ & $45.38 \pm 10.53^{a}$ & $64.92 \pm 15.67^{b}$ & $45.23 \pm 13.16^{a}$ & $56.35 \pm 9.34^{\mathrm{a}}$ & $43.18 \pm 3.65^{b}$ & $40.75 \pm 6.71^{b}$ & $42.44 \pm 10.13^{a}$ & $56.57 \pm 7.33^{b}$ & $44.03 \pm 12.81^{\mathrm{ab}}$ \\
\hline
\end{tabular}




\section{Figures}

Figure 1. Time course evolution of the prevalence and load for $V$. nigripulchritudo in the haemolymph of shrimps from the control and the probiotic challenged groups.

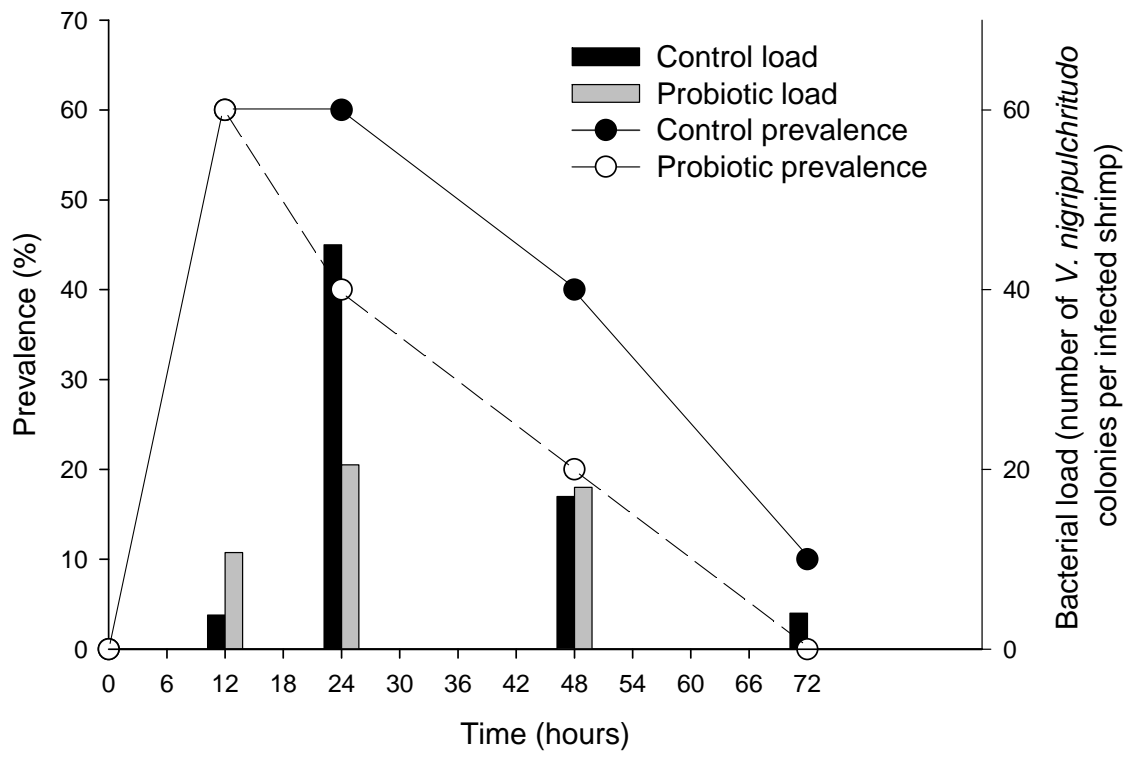

Figure 2. Number of dead and percentage mortality in the control and probiotic groups several hours after a $2 \mathrm{~h}$-immersion with $V$. nigripulchritudo SFn1 at $10^{5} \mathrm{CFU} \cdot \mathrm{ml}^{-1}$.

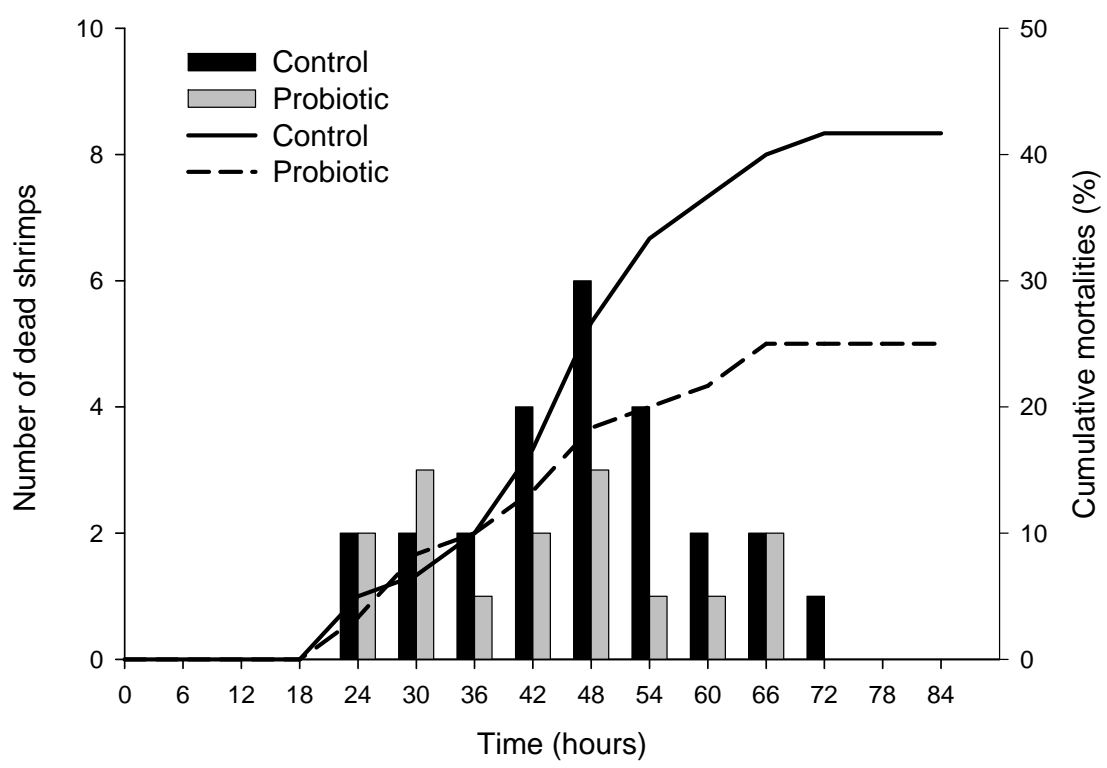


Figure 3. Relative Total antioxidant status (TAS) in the haemolymph and the digestive gland of shrimps from the control and the probiotic groups several hours after the infection by $V$. nigripulchritudo SFn1. A ratio of 1 corresponds to equal values for the infected and uninfected groups (Dash line).
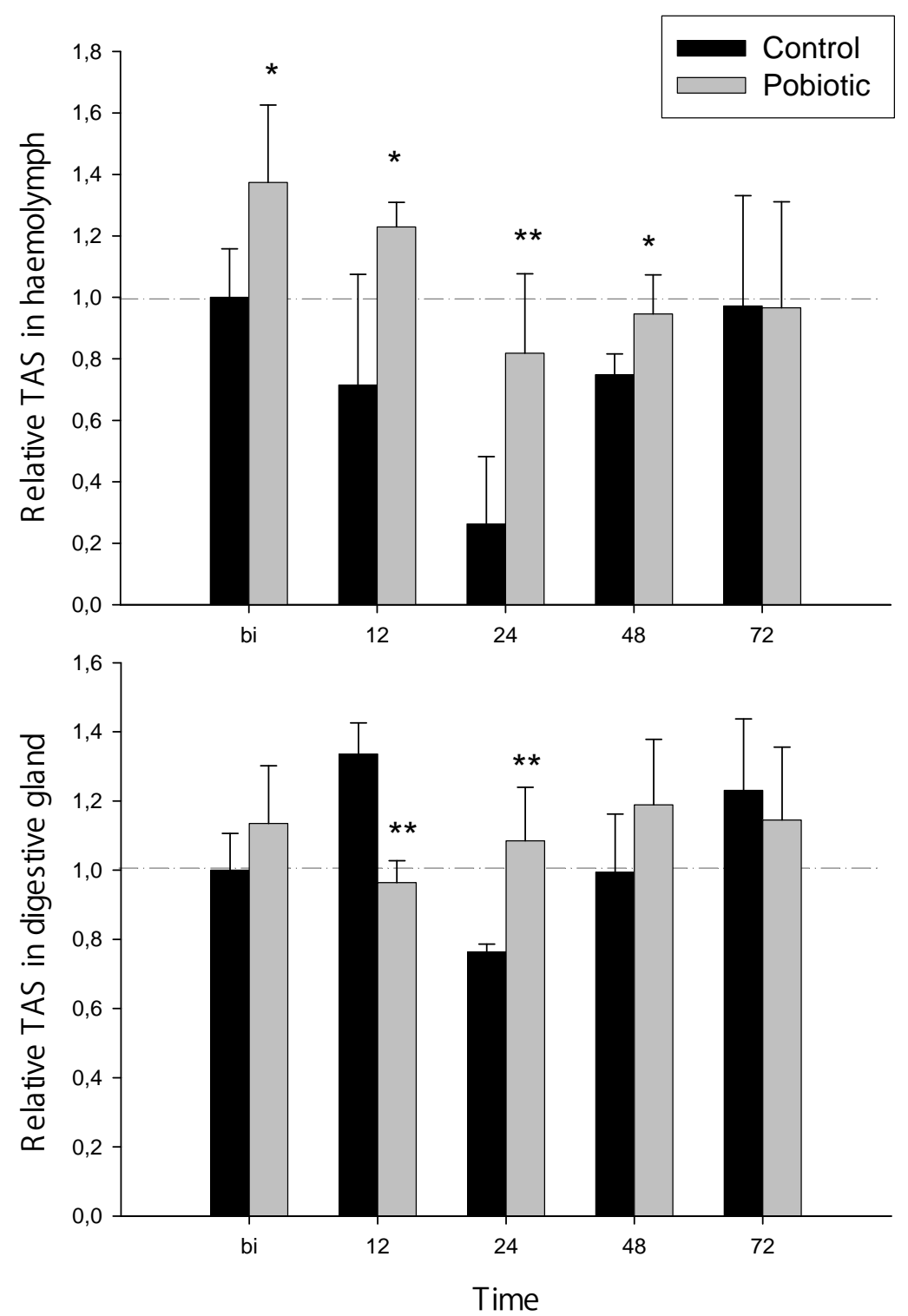
Figure 4. Relative antioxidant enzyme activities (SOD, CAT and Gpx) in the digestive gland of shrimps from the control and probiotic groups several hours after infection by $V$. nigripulchritudo SFn1. A ratio of 1 corresponds to equal values for the infected and uninfected groups (Dash line).

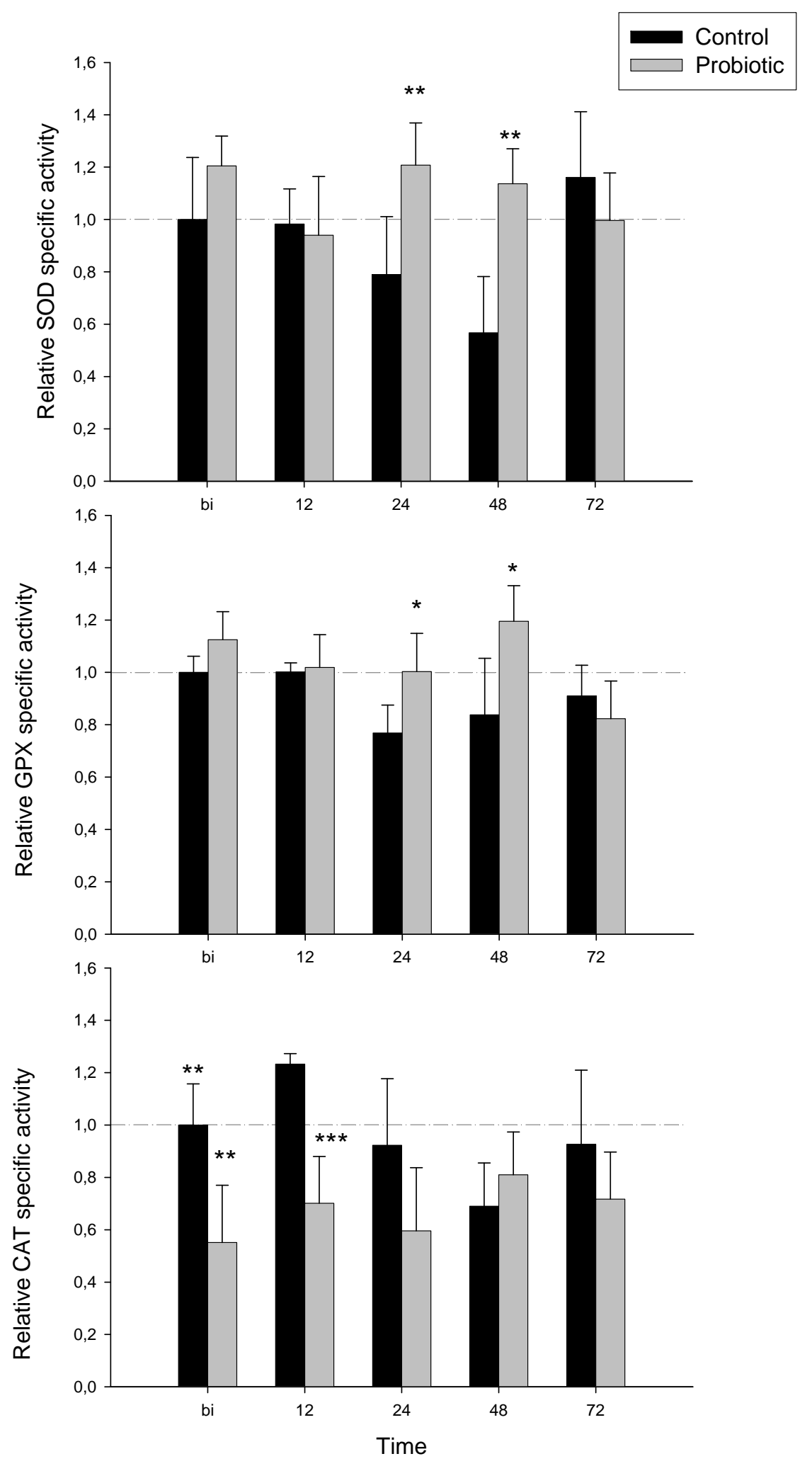


Figure 5. Relative MDA, carbonyl protein content and GSSG/GSH in the digestive gland of shrimps from the control and probiotic groups several hours after infection by $V$. nigripulchritudo SFn1. A ratio of 1 corresponds to equal values for the infected and uninfected groups (Dash line).
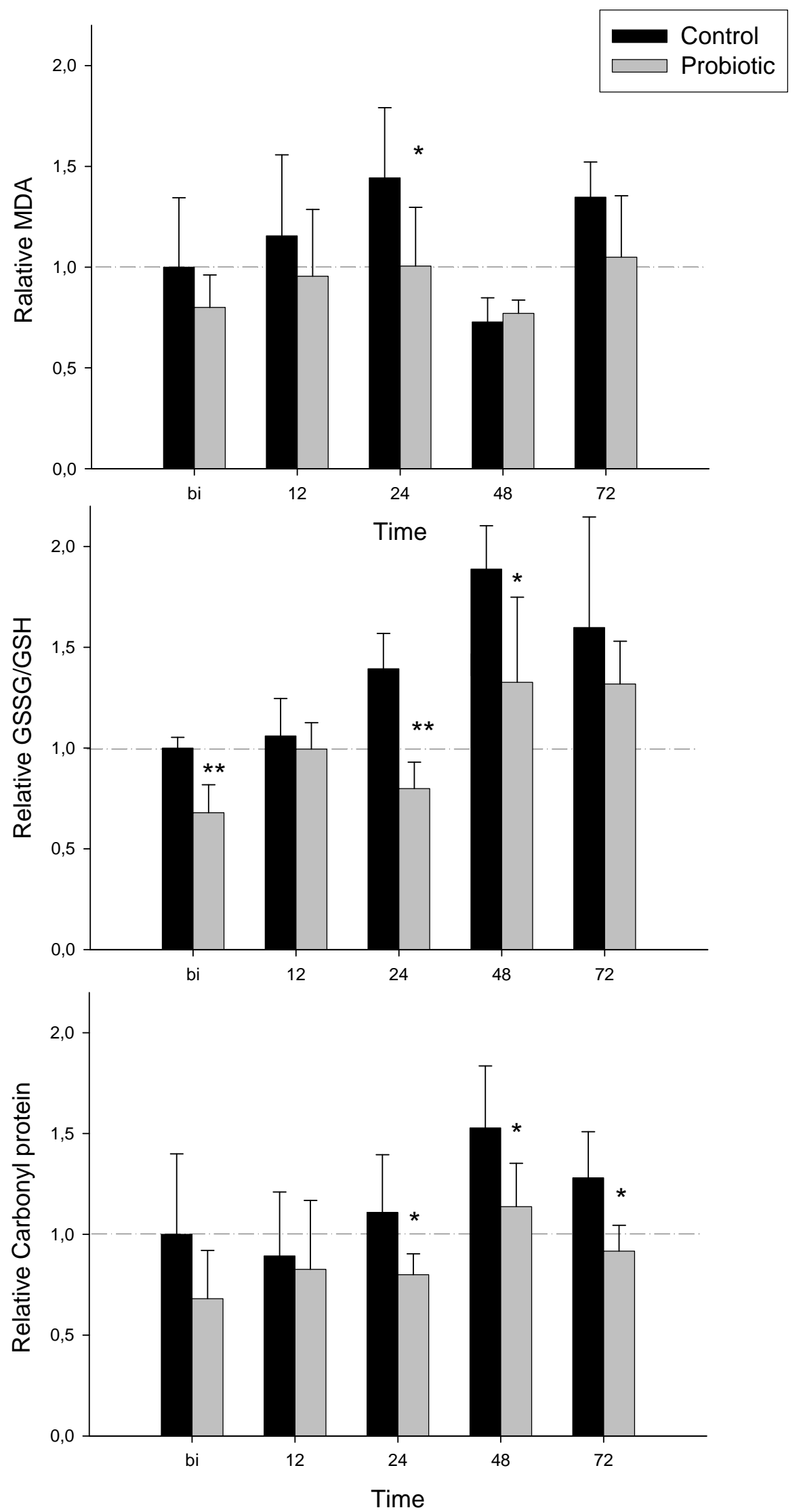